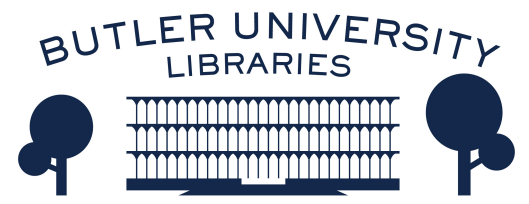

Journal of Hindu-Christian Studies

Volume 25

Article 6

November 2012

\title{
Yoga's 'A-Theistic'-Theism: A New Way of Thinking About God
}

Gerald J. Larson

Follow this and additional works at: https://digitalcommons.butler.edu/jhcs

Part of the Religion Commons

\section{Recommended Citation}

Larson, Gerald J. (2012) "Yoga's 'A-Theistic'-Theism: A New Way of Thinking About God," Journal of HinduChristian Studies: Vol. 25, Article 6.

Available at: https://doi.org/10.7825/2164-6279.1512

The Journal of Hindu-Christian Studies is a publication of the Society for Hindu-Christian Studies. The digital version is made available by Digital Commons @ Butler University. For questions about the Journal or the Society, please contact cbauman@butler.edu. For more information about Digital Commons @ Butler University, please contact digitalscholarship@butler.edu. 


\title{
Yoga's 'A-Theistic'-Theism: A New Way of Thinking About God
}

\author{
Gerald James Larson \\ Rabindranath Tagore Professor Emeritus of Indian Cultures \\ and Civilization, Indiana University, Bloomington, and \\ Professor Emeritus, Religious Studies, University of \\ California, Santa Barbara
}

\section{Introduction}

I want to begin with two intriguing quotations. ${ }^{1}$ The first is a passage quoted by John Cottingham in his book, The Spiritual Dimension, in which he mentions what C. S. Pierce calls "abductive inference," or "inference to the best explanation." The passage is from Simon Blackburn's book, Think. ${ }^{3}$ Says Blackburn,

Suppose you found yourself at school or university in a dormitory. Things are not too good. The roof leaks, there are rats about, the food is almost inedible, some students in fact starve to death. There is a closed door, behind which is the management, but the management never comes out. You get to speculate what the management must be like. Can you infer from the dormitory as you find it that the management, first, knows exactly what conditions are like, second, cares intensely for your welfare, and third, possesses unlimited resources for fixing things? The inference is crazy. You would be almost certain to infer that either the management doesn't know, doesn't care, or cannot do anything about it. Nor does it make things any better if occasionally you come across a student who declaims that he has become privy to the mind of the management, and is assured that the management indeed knows, cares and has resources and ability to do what it wants. The overwhelming inference is not that the management is like that, but that this student is deluded."

Cottingham then concludes,

Blackburn is arguing that if we start from the observed facts - the balance of evidence around us-then to draw the conclusion that it is created by an omniscient,

Dr. Gerald James Larson is Professor Emeritus, Religious Studies, UC Santa Barbara, and Tagore Professor Emeritus of Indian Cultures and Civilization, Indiana University, Bloomington. Dr. Larson is the author or editor of some twelve books and well over 100 scholarly articles on cross-cultural philosophy of religion, history of religions, classical Sanskrit and South Asian history and culture. His recent books include India's Agony Over Religion (SUNY Press, 1995, and Oxford University Press, Delhi, 1997), Changing Myths and Images (Indiana University Art Museum, 2000), and Religion and Personal Law in Secular India: A Call to Judgment (Indiana University Press, 2002, and Social Science Press, New Delhi, 2002). His most recent publication is Volume XII of the Encyclopedia of Indian Philosophies, co-edited with the late Dr. Ram Shankar Bhattacharya, entitled Yoga: India's Philosophy of Meditation (Delhi: Motilal Banarsidass, 2008). Also, a collection of essays has been published in his honour, Theory and Practice of Yoga: Essays in Honour of Gerald James Larson, edited by Knut A. Jacobsen (Leiden: Brill, 2005; paperback edition by Motilal Banarsidass, 2008). 
supremely benevolent, and omnipotent God is a vastly implausible, indeed, a crazy, inference. ${ }^{4}$

My second quote is from an essay by Gordon Kaufman as follows:

What could we possibly be imagining when we attempt to think of God as an allpowerful personal creator existing somehow before and independent of what we today call the universe? As far as we know, personal (agent) beings did not exist, and could not have existed, before billions of years of cosmic evolution of a very specific sort and then further billions of years of biological evolution also of a very specific sort had transpired... What possible content can this more or less traditional idea of God have...? ${ }^{5}$

\section{Some Recent Attacks on God and Religion}

As we are all aware, there have been several books of late that attack not only the notion of God but the very notion of religion itself, including the work of Sam Harris, Daniel C. Dennett, Richard Dawkins, Christopher Hitchins, et al. The primary reason for this recent series of attack-books is not difficult to identify. The books taken together are responding to the perceived growing influence of strident exclusivist religious behavior among certain Christian evangelical proselytizing groups, Islamist extremists who traffic in suicide bombing, right-wing Zionist groups whose violent rhetoric denigrates Palestinian Arabs, extremist "Hindu-tva" groups who have encouraged on occasion violence against Muslims and Muslim monuments such as the Babri Masjid, and on and on and on. Strident exclusivist religiosity appears to be alive and well almost everywhere-the dark underside, as it were, of the process of globalization.

While I am sympathetic to the work of Harris, Dennett, Dawkins and Hitchens in regard to their critiques of mindless religiosity, I am also deeply troubled by their own propensity to be more than a little strident, exclusivist and mindless in their own work.
Their work often borders on an arrogant and narrow-minded "scientism" in many ways as unattractive as the traditions they are criticizing, and their knowledge of the history of religions appears to be confined to what they learned in some mandatory sunday school from which they are still engaged in adolescent rebellion. To cite only one glaring example, this is how Dawkins opens the discussion of his second chapter regarding "The God Hypothesis."

The God of the old Testament is arguably the most unpleasant character in all fiction: jealous and proud of it; a petty, unjust, unforgiving control-freak; a vindictive, bloodthirsty ethnic cleanser; a misogynistic, homophobic, racist, infanticidal, genocidal, filicidal, pestilential, megalomaniacal, sadomasochistic, capriciously malevolent bully. ${ }^{6}$

Whatever else one might wish to say about such a passage, that it represents an openminded invitation to discuss "the God hypothesis" is surely not one of the things.

Regardless of these various spitting matches between believers in the God of Abraham, Isaac, Jesus and Muhammad and their "cultured despisers", it is, I think, a fair observation that conventional conceptualizations of theism, whether of the Jewish, Christian, or Muslim sort, or of the Bhakti, Tantric or Dharmakāya sort are highly questionable as plausible or warranted assertions in contemporary philosophical or theological discourse.

\section{The Notion of "God" in Yoga}

Interestingly different, however, is a notion of God (Iśvara) in ancient Indian thought that formulates the conceptualization of "theism" in an unusual manner. I have in mind the notion of "God" in the classical Yoga philosophy of Patañjali, or simply, Pātañjala-Yoga. As most of you know, the systems of Classical Sāṃkhya and Pātañjala Yoga are usually taken together as a twin-pair or a "common tradition" (samāna-tantra) in Indian philosophy. The pair Sāmkhya and Yoga have to do primarily with meditation, with Sāmkhya said to be the theory 
of meditation, and Yoga usually described as the practical working out of the theory. The main difference between the two, according to almost all the books on Indian philosophy, is that Sāmkhya is 'a-theistic', or perhaps better, non-theistic, whereas Yoga is theistic, or, in other words, accepts some sort of notion about God. No one says very much more about Yoga's notion of God, however, and most interpreters have assumed that Yoga's theism is typical of one or another of the types of bhakti ideology in devotional Hindu spirituality.

In fact, however, I want to argue that the Yoga notion of God is peculiar, even eccentric, not only in terms of Indian thought but, rather, in terms of any of the conventional conceptualizations regarding God, and I would like to argue, further, that the manner in which classical Yoga philosophy deals with the notion of God may offer some interesting perspectives for re-thinking the problem of God in contemporary discussions of the issue.

\section{Patañjali's Yogasūtra, Book One (The Samādhi Pāda)}

I shall proceed in the following manner. First, I want to summarize briefly what Patañjali's Yogasūtra (hereafter YS) says about God. ${ }^{7}$ Second, I want to discuss four sorts of "de-constructions" and/or "reconceptualizations" that such a notion of God in Yoga entails. Finally, I want to conclude by highlighting what we might learn from classical Yoga philosophy regarding a unique approach to the problem of theism.

First, then, what do we learn about the notion of God in Patañjali's YS? The issue is discussed primarily in the first book, or, in other words, Pāda I, the Samādhi Pāda, sūtras 23 through 29. God is also mentioned in Pāda II, sūtras 1 and 32, and then extensively in the full cosmology set forth in Pāda III, sūtra 26 with the commentaries of Vysa and Vācaspatimiśra. In Pāda I, the definition of Yoga, the nature of ordinary awareness (that is, the citta-vrttis), and the ultimate goal of Yoga (that is, the attainment of pure consciousness or purusa) are all set forth. Then the principal means for attaining cessation of the functioning of ordinary awareness, namely, Yogic praxis (abhyāsa) and renunciation (vairāgya) are discussed. Then follow the four levels of "concentration" or samädhi that involve some sort of intentional object (samprajñātasamādhis), that is, an empirical object (vitarka), a rational or intellectual object (vicāra), an aesthetic object (ānanda), and, fourth, one's own ordinary subjective or self-awareness as an object (asmitā).

Thereafter, it is suggested that there can be yet another intentional object, or samprajñatasamādhi, namely, God (İ́vara).

Says Patañjali:

I.23. "Or, concentration having an object (samprajñāta-samādhi) can also be attained through focusing on God (as the object of meditation).

(iśsvara-pranidhānād vā)

I.24. God is a particular or unique consciousness (purusa) among consciousness-es (purusa-s), untouched by the afflictions, karmic tendencies, karmic fruits and long-term karmic predispositions (that are characteristic of all other sentient beings associated with purusa-s).

(kleśa-karma-vipāka-āśayair aparāmrșța puruṣa-viśeșa iśvara')

I.25. In God the pinnacle of omniscience has been attained.

(tatra nir-atiśayam sarva-jña-bījam) I.26. (God is) the exemplar (guru, "teacher") of all preceding teachers inasmuch as God is not limited by time.

(pūrveșām api guruḥ kālena anavacchedāt)

I.27. The verbal expression for God is the sacred syllable (pranava) (or, in other words, the syllable $O M)$.

\section{(tasya vācakah pranavah)}

I.28. Repetition of it [the sacred syllable] (and) meditation on the object of the expression [namely, God] [should be practiced in order to achieve samādhi].

\section{(taj-japas tad-artha-bhāvanam)}

I.29. Then, (when concentration has been properly cultivated) there is a going over into one's own pure consciousness and the disappearance of the obstacles as well.

(tatah pratyakcetanādhigamo 'py antarāya-abhāvaś ca) 
The description of God in these sūtras, in my judgment, is unique in the general history of religions, both in terms of the great Abrahamic religions (Judaism, Christianity and Islam) as well as the notions of God in South Asian and East Asian traditions. In order to understand this unique Yogic notion of God, one is required to re-think, or, to "reconstruct," or, if you prefer, to "de-construct" one's usual ways of thinking about God. To grasp the unique Yogic view of God requires four kinds of "de-constructive" and/or "reconstructive" thinking, namely,

(I) An act of de-personalization;

(II) An act of de-anthromorphism;

(III) An act of de-mythologization; and, finally

(IV) An act of de-conceptualization.

Alternatively, one might put the matter simply in the following way:

(I) For Pātañjala Yoga, the notion of God is never personal.

(II) For Yoga, there is no notion of God as creator, that is, no notion of God on analogy with a human "agent" that acts in creating or fashioning.

(III) For Yoga, the notion of God cannot be reduced to any one of the conventional religions of the world.

(IV) Finally, the notion of God has very little to do with philosophical conceptualization.

Let me comment on each one of these four.

(I) First, An Act of De-personalizationor, for Yoga, the notion of God is never personal.

The idea of the person or ego, called asmitā in Yoga (or ahaṃkāra in Sāṃkhya), is a fundamental "affliction" (kleśa) that must be overcome. Of course, each of us has our personal identity, or even a variety of personal identities, that make possible our everyday functioning, or what C. G. Jung called our "egomasks". The concept of the person or ego is basically a flawed notion, however, and who and what we are-that is, our deeper selfhood- is much broader and complex than our everyday notion of "person" would allow. To then project the notion of "person" on to the notion of God is to compound our confusion, both in regard to our own authentic selfhood, as well as any understanding of the nature of God.

There are vast depths of unconscious processes, both physical and psychological, that take place apart from our personal awareness. More recently in the fields of cognitive psychology and philosophy of mind, the notion of "person" or what philosophers of mind call "folk psychology," or, in other words, our ordinary self-awareness has been found to be seriously incorrect. Our traditional understanding of the "person" or the "selfconscious mind" as "having" certain sensations or being the subject of certain attitudes may be so fundamentally naive and simplistic as to be flat out wrong or false. One thinks here of some of the fascinating recent work in cognitive psychology and neuroscience, for example, Antonio Damasio's Self Comes to Mind (Pantheon, 2010), V. S. Ramachandran's The Tell-Tale Brain (Norton, 2011), Michael Gazzaniga's Who's in Charge? Free Will and the Science of the Brain (Harper-Collins, 2011), and David Eagleman's Incognito: The Secret Lives of the Brain (Pantheon, 2011), all of which books call into question naïve notions of the "person" in terms of human understanding, much less what "person" could possibly mean in speaking about God.

In this regard, I want to share a story told to me by Dr. P. N. Tandon, President of the National Brain Research Centre, based in Gurgaon, Haryana. Dr. Tandon is a brain surgeon (neurosurgeon). On a certain occasion, a woman was brought to his hospital suffering from a brain hemorrhage. Following surgery to stop the bleeding, the woman became comatose and was not expected to live. Dr. Tandon and another doctor were discussing her case while in the patient's room, but then they decided not to discuss anything further about her, since there was no way of knowing whether the woman was able to hear or understand their conversation. Shortly thereafter, another doctor was in the woman's room and started reciting a Bengali poem of Tagore to a nurse in 
the room. The doctor could not remember the final line in the poem, at which point the comatose woman then proceeded to recite the final line in clear and correct Bengali. The woman died some two days later, and when her brain was opened during the autopsy, Dr. Tandon described the woman's brain as being little more than "porridge," in other words, completely dysfunctional. Presumably there was some sort of memory residue deep in her awareness, possibly associated with some powerful emotional experience in her life, to which she was somehow able to respond even while in a deep coma. There is no satisfactory scientific explanation, although cases such as this suggest that cognitive and linguistic functioning operate within a larger brain system that transcends our conventional understanding of personal awareness.

In terms of the classical philosophy of Yoga, the point here is that to take our problematic and deeply flawed notion of the "person" and to project that flawed notion on to God is to miss the point of what God could possibly be. Surely our notion of the personal, or egoity, cannot be the case in terms of understanding the nature or essence of God. For Yoga, God is "untouched" by the "affliction" known as egoity-God, in other words, is never personal.

(II) Second, an Act of Deanthromorphism-or, for Yoga, there is no notion of God as creator, that is, no notion of God on analogy with a human "agent" that acts in creating or fashioning.

The world has no beginning in time. It is, according to Yoga, beginningless (an-ādi), although there are periods of dissolution (pralaya and mahāpralaya), when the world dissolves back into its primordial condition, after which other periods of manifestation will take place. This is a sort of theory, as it were, to use a contemporary idiom, of multiple universes in which a sequence of "big bangs" occur after periods of entropy burn-outsendless in that sense!

The point, however, is that our human species is hardly central in the scheme of things, and it is certainly not the case, according to Yoga, that the universe was created for human beings to be sovereign. Any philosophy of humanism (that is, the centrality of the human) whether religious or secular, is like the notion of the "ego" or "person." The human species is only one rather minor species in the great hierarchies of sentient beings. More than that, because of the Yoga notion of Karma and rebirth that is beginningless, hence infinite, at one time or another, we have cycled into every conceivable form of sentient existence.

For Yoga, the human is hardly central and the notion of God as creator is as incoherent as the notion of God as person. Regarding the insignificance of the human in the larger framework of Nature, E. O. Wilson in his fascinating book, Creation, offers two contrasting comments about the vast expanse of nature. From one perspective we are becoming increasingly aware that there are vast numbers of species all around us. ${ }^{8}$ Says Wilson, "In one gram of soil, less than a handful, live on the order of 10 billion bacteria belonging to as many as 6000 species." At the same time, however, Wilson also comments that in the context of Nature as a whole,

...our [human] biomass is almost invisibly small. It is mathematically possible to logstack all the people on Earth into a single block of one cubic mile and lower them out of sight in a remote part of the Grand Canyon.

....[yet] The destructive power of Homo sapiens has no limit. ...humanity is already the first species in the history of life to become a geophysical force. ${ }^{9}$

Thus, there is the interesting paradox that an insignificant amount of biomass (that is, the human portion of the hierarchies of life) nevertheless by its destructive excesses and misuse of resources threatens the ecology of the entire planet. Ours is surely a predator species in this regard. Clearly it is becoming increasingly essential to see our human place within the hierarchies of life in a much more realistic and mature manner. The notion of a 
personal God, whether the Father God of the great Abrahamic religions or the bhakti-saviors of Hindu and Buddhist piety, who create the world for the sake of human well being and worldly order, is seriously in need of reformulation. According to the philosophy of Yoga, the very notion of God as creator is fundamentally incoherent and remarkably naive.

(III) Third, An Act of Demythologization-or, for Yoga, the notion of God cannot be reduced to any one of the conventional religions of the world.

In YS III.26, the detailed cosmology of Yoga is described, ranging from the seven cosmic regions (Satya-loka, and so forth) down through the lowest hells. The locations of the Videhas and Prakrtilayas and the released Yogins are described, and in YS I.26 (mainly in the commentaries) the various traditional religious traditions are discussed, including the Buddhist, Jaina, Śaiva, Vaiṣnava, and so forth. One could easily add the great Abrahamic religions, namely the Jewish, Christian and Islamic traditions as well. God or Íśvara, however, according to Yoga, has nothing to do with any of these. God is totally outside all such networks, since God cannot be encompassed by any temporal framework. Again, as YS I.26 puts it, "(God is) the teacher even of all preceding teachers inasmuch as God is not limited by time."

Here, one thinks, of course, of the great Meister Eckhart (1260-1327), who in his Latin essays and German sermons, introduces the notion of "Gottheit" or "Godness" behind the God of the Christian Trinity-God the Father, God the Son and God the Holy Spirit. Eckhart was accused and convicted of heresy, and specifically the heresy of atheism, since he suggested that the Christian doctrine of God must be subsumed under the greater notion of "Gottheit," or God-ness.

Or, again, one thinks of the $20^{\text {th }}$ century theologian, Paul Tillich, who likewise rejected the traditional Abrahamic notion of God, whether Jewish, Christian or Islamic. The notion of God, says Tillich, is only a symbolic formulation. What is more basic is what Tillich called, the "ground of Being," or "Being itself." Like Eckhart, Tillich also was often called an atheist.

And, of course, there is the great Śamkara, who in the famous Adhyāsa-bhāṣya, his brilliant introduction to the commentary on the Brahmasūtra, argues that even the contents of the Vedic corpus, including all of the utterances in the Upanișads are, finally, only avidyā and Māyā. God is only sa-guna, a lower symbolic formulation. Only the attributeless or nirguna Absolute (Brahman) truly is! Like Eckhart in the medieval period, so the great Samkara in his time was attacked by nonAdvaitins for his atheism.

Regarding this notion of demythologization, of course, Yoga would concur with Śamkara and the Advaitins, and, for that matter, with Meister as well. God, according to the philosophy of Yoga, transcends all cultural and religious traditions. $\mathrm{He}$ is outside or beyond the Cosmic Egg, as it were. It is almost as if one must become an 'a-theist' in terms of conventional religion if one is properly to understand the notion of the divine.

(IV) Finally, fourth, An Act of Deconceptualization, or, for Yoga the notion of God has very little to do with philosophical conceptualization.

In Vyāsa's commentary on YS I.2, he concludes with the following comment. "Yogins attain what they call the supreme realization (prasamkhyāna) wherein they come to see the difference between pure immutable consciousness in which all objects or contents are reflected, on the one hand, and the realm of Nature (sattva) which is also present. Becoming, then, indifferent even to that distinction, they bring to cessation even that realization. They reach the condition where only some residual predispositions (samskāras) remain. This is the samädhi known as "seedless" (nirbija) or "without any object" ( $a$ samprajñāta). Therein nothing at all is known." One moves, in other words, beyond all conceptualization wherein one attains the realization of the presence of "eternal excellence," a condition of the quiescent co- 
presence of citi-śakti (pure consciousness) and "perfect citta-sattva"-in other words, the realization of the distinction between pure consciousness and the fullness of the natural world.

\section{Conclusion}

Who or what, then, is this God of Yoga? God is not a person. God is not a creator. God is certainly not a "he" or "she." God is not captured by religion. God cannot be conceptualized by philosophy. Says Yoga: (I.24:) "God is a particular or unique consciousness (purusa) among consciousnesses (purusa-s), untouched by the afflictions, karmic tendencies, karmic fruits and long-term karmic predispositions (that are characteristic of all other sentient beings associated with purușas)."

If, according to Yoga, God is not touched by afflictions, actions, the consequences of actions, and the resulting traces and/or predispositions, then obviously God cannot be a creator in any meaningful sense, nor can God be personal in any intelligible sense. God as consciousness cannot be a thing or entity, and because consciousness is content-less or objectless, it can only appear as what it is not. What distinguishes God can only be what consciousness, untouched by afflictions, actions, consequences and predispositions, appears not to be. What appears not to be in such an environment can only be "perfect sattva" in which rajas and tamas, though present, are inoperative (and see Vyāsa on YS I24). The environment of "perfect citta-sattva," in turn, which pure consciousness appears not to be, functions by way of making possible a non-intentional awareness of the presence of pure consciousness, as being distinct from itself. God, then, is the "eternal excellence" (śâśvatika-utkarśa) of the presence of "perfect sattva" and contentless or object-less consciousness (purușa) .

The Vyāsa Bhāya (YS I.24), then, poses the question as to whether there is some sort of proof or warrant for the "eternal excellence" of such a God. The answer is that the proof is to be found in the saastra. According to Vācaspatimiśra, Śāstra means in Śruti, Smṛti,
Itihāsa and Purāna. But what, then, is the proof or warrant for the validity of the Sāstra, asks the Vyāsa Bhāṣya? The answer is that the warrant is in "perfect sattva". The truth in Sāstra, in other words, is the content illuminated by citta-sattva when rajas and tamas have become inoperative. God is the "eternal excellence" in which pure consciousness and "perfect sattva" are present to one another, a dyadic substantive transcendence in which the "pinnacle of omniscience" has been attained (YS I.25).

God for Yoga, then, serves both as a regulative idea and as an interesting ontological argument. God is a regulative idea in the sense that even at the height or pinnacle of what can be known, God always has a body distinct from pure consciousness, namely, perfect sattva. Even when the entire manifest world dissolves in the mahãpralaya, God as the "seed of the omniscient" (sarvajña-bija) continues to abide, inasmuch as God is the "eternal excellence" which must always be! God for Yoga is also an interesting ontological argument in the sense that that "than which nothing greater can be conceived," namely, pure, contentless consciousness, can only show itself, or, if you will, reveal itself, as the eternal presence in the reflective discernment of "perfect sattva." In this sense, God for Yoga is a mediating position between the theology of Advaita Vedānta and the "theology" of Buddhist thought. In Vedānta, citta-sattva dissolves as an ontological principle in Māyā, and there is, finally, only Brahman. In Buddhist thought, citta as temporal becoming is ultimate, and beyond citta there is no substantive transcendence.

Finally, of course, as the Vyāsa Bhāṣya has clearly indicated (see comment on YS I.2), our halting attempt at theological discourse reaches the point beyond which ordinary words cannot take us, and we can only say with Wittgenstein:

\footnotetext{
Die Grenzen der Sprache...die Grenzen meiner Welt bedeuten;

Wovon man nicht sprechen kann, darüber muss man schweigen.
} 
"The limits of language...inform the limits of my world;

What we cannot speak of we must pass over in silence." (Cottingham, p. 120)

\section{Notes}

${ }^{1}$ A considerably expanded version of this paper may be found in the upcoming Felicitation Volume in honor of T.S. Rukmani to be published by D.K. Publishers, Delhi, 2012, entitled "Yoga's Theism: A New Way of Thinking about God," pp. 78-95. See also Gerald James Larson and Ram Shankar Bhattacharya, eds., Yoga: India's Philosophy of Meditation, Volume XII, Encyclopedia of Indian Philosophies, General Editor, Karl H. Potter, section in Introduction entitled, "The Theism of Yoga," Delhi: Motilal Banarsidass, 2008, pp. 91 ff. Finally, see Gerald James Larson, "Pātañjala Yoga in Practice," in David Gordon White, ed., Yoga in Practice, Princeton University Press, 2012, pp. 73-96.

2 John Cottingham, The Spiritual Dimension: Religion, Philosophy and Human Value (Cambridge: Cambridge University Press, 2005), p. 19.

3 Simon Blackburn, Think (Oxford: Oxford University Press, 1999), p. 20.

${ }^{4}$ Cottingham, p. 20.

${ }^{5}$ Gordon Kaufman, Presidential Address, Journal of the American Academy of Religion, Volume 72, No. 4, December 2004, p. 1004.

${ }^{6}$ Richard Dawkins, The God Delusion (New York: Houghton Mifflin, 2006), p. 31.

${ }^{7}$ The version of the YS used for this essay is Gerald James Larson and Ram Shankar Bhattacharya, eds., Yoga: India's Philosophy of Meditation, Volume XII, Encyclopedia of Indian Philosophies. General Editor: Karl H. Potter (Delhi: Motilal Banarsidass, 2008), pp. 161-183.

8 E. O. Wilson, Creation (New York: W. W. Norton, 2006), p. 29.

${ }^{9}$ Ibid. 